\title{
RESPONSABILIDADE CIVIL DECORRENTE DO ABANDONO AFETIVO DOS PAIS PERANTE SEUS FILHOS
}

\section{CIVIL LIABILITY OF ABANDONMENT OF AFFECTIVE BY PARENTS CHILDREN}

\author{
Justiny Rodrigues Carvalho ${ }^{1}$ \\ Vinicius Pinheiro Marques ${ }^{2}$
}

\section{RESUMO}

O presente artigo aborda a possibilidade de responsabilização civil dos pais que abandonam afetivamente seus filhos, trata-se de um tema polêmico e controverso jurisprudencial e doutrinariamente. Apesar do posicionamento favorável da doutrina majoritária, os Tribunais na maioria dos seus julgados têm entendido pelo não cabimento de indenização em caso de abandono afetivo. Ante a dicotomia de posicionamentos e a fim de corroborar o entendimento de que 0 abandono afetivo paterno e/ou materno culmina em um dano moral passível de indenização, num primeiro momento o presente trabalho discorrerá sobre a teoria geral da responsabilidade civil, em seguida apresentará os princípios que devem nortear as relações de família e os deveres legalmente impostos aos pais para com seus filhos, com enfoque naqueles inerentes ao poder familiar. Por fim, far-se-á uma minuciosa análise dos pressupostos necessários a configurar a obrigação dos pais negligentes de reparar pecuniariamente o dano moral que causaram em seus filhos, bem como do posicionamento do Superior Tribunal de Justiça acerca do tema.

Palavras-chave: responsabilidade civil, poder familiar, abandono afetivo, dano moral, indenização.

\section{ABSTRACT}

This paper discusses the possibility of civil liability of parents who abandon their children affectively, this is a controversial and contentious issue in the doctrine and jurisprudence. Despite the favorable position of the majority doctrine, the courts in most of its decisions have not understood by the indemnity in case of . Due to the dichotomy of positions and in order to corroborate the view that parental emotional neglect and / or breast culminates in moral damages subject to indemnification, at first this paper will discuss the general theory of liability, then present the principles which should govern the relations of family and the duties legally imposed on the parents to their children, focusing on those inherent in the family Power. Finally, a thorough analysis of the assumptions necessary to configure the obligation of

\footnotetext{
${ }^{1}$ Bacharel em Direito pela Faculdade de Ciências Jurídicas de Paraíso do Tocantins (FCJP). Advogada. E-mail: justiny.rodrigues@hotmail.com

${ }^{2}$ Mestre em Prestação Jurisdicional pela Universidade Federal do Tocantins. Professor dos Cursos de Graduação e Pós-Graduação Lato Sensu em Direito da Universidade Federal do Tocantins (UFT) e da Faculdade Católica do Tocantins (FACTO). E-mail: viniciusmarques@uft.edu.br
} 
neglectful parents monetized repair the moral damage caused to their children, as well as the positioning of the Superior Court shall be effected on the subject.

Keywords: civil liability, family power, affective abandonment, moral damage, indemnification.

\section{INTRODUÇÃO}

As relações familiares sofreram expressivas mudanças com o decurso do tempo, pautando-se atualmente não mais no autoritarismo e sim no afeto e respeito mútuos.

Com o advento da Constituição Federal de 1988 o direito privado, bem como o direito de família, passaram a se submeter ao princípio da dignidade da pessoa humana, princípio este que foi elevado pela Lei Maior ao patamar mais alto do ordenamento jurídico.

O Direito pátrio e os compromissos internacionais dos quais o Brasil é signatário garantem aos filhos menores o direito ao convívio familiar, à criação, à educação e à companhia dos pais, sendo que estes têm o dever de propiciar à prole todas as condições necessárias ao seu saudável desenvolvimento psíquico, caso abstenham-se de tal dever estarão violando, dentre outros preceitos, o princípio da dignidade da pessoa humana.

A Constituição Federal de 1988 atribui à família, à sociedade e ao Estado, dentre outras obrigações relacionadas à criança e ao adolescente, o dever de assegurar a estes o direito à vida, à saúde, à alimentação, à educação, ao lazer, à profissionalização, à cultura, à dignidade, ao respeito, à liberdade e à convivência familiar e comunitária, além de resguardá-los de toda forma de negligência, discriminação, exploração, violência, crueldade e opressão.

No entanto, casos de indiferença, desprezo e abandono de crianças e adolescentes por um de seus pais ou até mesmo por ambos ocorrem diuturnamente e os efeitos psíquicos desta negligência, principalmente quando ocorrida na infância e adolescência, irão certamente perdurar durante toda a vida do filho negligenciado.

$\mathrm{Na}$ última década houve um significativo aumento no número de demandas judiciais intentadas com a pretensão de ver reparado o dano moral causado pelo abandono afetivo dos pais, tal fato culminou no impasse de entendimento entre doutrina e jurisprudência quanto a admissibilidade da responsabilização civil dos 
pais negligentes, gerando acirradas discussões fundadas nos mais diversos argumentos.

De um lado a jurisprudência vem se posicionando contra a responsabilidade civil dos pais por abandono afetivo, sob alegação precípua de que não se pode coagir alguém a amar outra pessoa, constituindo o afeto uma mera faculdade dos pais. Defendem os juristas que o abando afetivo não é um ilícito civil, sendo a destituição do poder familiar a punição cabível para tal conduta omissiva.

Noutra vertente, a doutrina majoritária refuta o entendimento dos tribunais defendendo que o ordenamento jurídico pátrio tutela os direitos da criança e do adolescente e impõe aos pais o dever de assisti-los imaterialmente, sendo que o descumprimento de tal direito-dever poderá sim ensejar a responsabilização dos pais em decorrência dos danos morais causados aos filhos.

Diante do retro transcrito confronto de ideias indaga-se: É cabível a ação de indenização por perdas e danos em face dos genitores que abandonam afetivamente seus filhos? Se cabível, quais os critérios a serem utilizados para a fixação do quantum?

A incomensurável relevância do tema decorre do anseio tanto dos operadores do direito, quanto da sociedade e principalmente das vítimas do descaso de seus pais de que o direito avance, acompanhe e se adéqüe às mudanças sociais, de forma a ser capaz de dirimir as novas lides e proporcionar as soluções mais justas possíveis.

Dentre outros fundamentos, a necessidade de discorrer sobre a possibilidade de responsabilização civil dos pais que abandonam afetivamente seus filhos adveio do dever jurídico que aqueles, a sociedade e o Estado têm de proteger os interesses e direitos das crianças e adolescentes, colocando-os a salvo de toda forma de negligência, inclusive do abandono imaterial.

Nesse diapasão, constata-se que o descumprimento do dever de prestar assistência imaterial aos filhos não é apenas moralmente repudiado, mas também juridicamente rechaçado, sendo que o intento precípuo do presente estudo é justamente evidenciar a existência da obrigação dos pais de reparar o dano moral sofrido pelos filhos em decorrência do abandono afetivo.

O método de pesquisa escolhido foi o dedutivo, uma vez que o presente estudo partirá do antecedente ao conseqüente, o que significa dizer que foram formuladas premissas com intuito de se chegar à conclusão de que o dano moral 
acarretado pelo abandono afetivo dos pais é sim passível de reparação na esfera civil. A pesquisa realizada tem natureza qualitativa da análise dos dados obtidos através de uma técnica de pesquisa documental indireta com base nas legislações, jurisprudências e doutrinas.

\section{PRINCÍPIOS NORTEADORES DO DIREITO DE FAMÍLIA}

\subsection{Breves considerações}

Derivada do latim a palavra princípio significa aquele ou aquilo que vem primeiro, "daí dizer-se princípio aquilo que funciona como origem, começo ou base, tanto do agir teórico quanto do agir prático do ser humano" (MARÇAL, 2013, p. 15).

O mesmo autor apresenta um abrangente e completo conceito de princípios, que segundo ele são

[...] ou informações ou diretrizes, expressas em enunciados lingüísticos expositivos (um axioma ou uma hipótese, por exemplo) ou prescritivos (uma regra ou um comando), cujo conteúdo é constituído por conhecimentos, normas, valores ou objetivos, e que, do ponto de vista metodológico, servem de base sobre a qual se desenvolvem construções teóricas discursivas específicas (teorias e sistemas especificamente determinados) ou sobre que se estruturam funções e justificações do agir prático (marco ou referencial operatório ou regulativo). (MARÇAL, 2013, p.15).

Acerca dos princípios constitucionais Pazzaglini Filho (2003, p. 9-10) salienta que os mesmos estão no "vértice da pirâmide normativa e expressam os valores transcedentais (éticos, sociais, políticos e jurídicos) arraigados ou consolidados na sociedade, convertidos pelo legislador constituinte em princípios jurídicos". Nesse sentido, para o referido autor os princípios constitucionais direcionam e fundamentam o processo de formação, elaboração de conteúdo, bem como de aplicação a de todas as demais normas componentes do ordenamento jurídico. Dessa forma o vigente Código Civil nasceu à luz dos princípios e normas constitucionais.

As alterações introduzidas visam preservar a coesão familiar e os valores culturais, conferindo-se à família moderna um tratamento mais consentâneo à realidade social, atendendo-se às necessidades da prole e de afeição entre os cônjuges ou companheiros e aos elevados interesses da sociedade. (GONÇALVES, 2013 p.21-22) 
Portanto, faz-se mister abordar, ainda que sucintamente, alguns dos princípios aplicados ao direito de família, uma vez que respaldam, explicam e fundamentam a interpretação das normas que regem as relações familiares.

\subsection{Princípio da dignidade da pessoa humana}

De acordo com Gagliano e Pamplona Filho (2011, p.74) no âmbito jurídico a "dignidade traduz um valor fundamental de respeito à existência humana, segundo as suas possibilidades e expectativas, patrimoniais e afetivas, indispensáveis a sua realização pessoal e à busca da felicidade".

A dignidade da pessoa humana ao ser consagrada pela Contituição Federal de 1988, em seu artigo 1ํㅡㄴ III, como um fundamento do Estado Democrático de Direito Brasileiro, passou a ser considerada como um macroprincípio sobre o qual está alicerçado todo o ordenamento jurídico nacional.

Sendo assim o direito de família, por ser "o mais humano de todos os ramos do direito" (GONÇALVES, 2013, p.22) é o que possui a maior incidência do princípio da dignidade da pessoa humana.

\section{Explana Dias}

A dignidade da pessoa humana encontra na família o solo apropriado para florescer. A ordem constitucional dá-lhe especial proteção independentemente de sua origem. A multiplicação das entidades familiares preserva e desenvolve as qualidades mais relevantes entre os familiares 0 afeto, a solidariedade, a união, o respeito, a confiança, o amor, o projeto de vida comum, permitindo o pleno desenvolvimento pessoal e social de cada partícipe com base em ideais pluralistas, solidaristas, democráticos e humanistas. (DIAS, 2009, p.62).

A corroborar o exposto acima, insta trazer a lume os dizeres de Lôbo

Atualmente, a família converteu-se em locus de realização existencial de cada um de seus membros e de espaço preferencial de afirmação de suas dignidades. Dessa forma, os valores coletivos da família e os pessoais de cada membro devem buscar permanentemente o equilíbrio, "em clima de felicidade, amor e compreensão". Consumaram-se na ordem jurídica as condições e possibilidades para que as pessoas, no âmbito das relações familiares, realizem e respeitem reciprocamente suas dignidades como pais, filhos, cônjuges, companheiros, parentes, crianças, idosos, ainda que a dura realidade da vida nem sempre corresponda a esse desiderato. (LOBO, 2011, p.62). 
Para Delgado (2006, p.705) o princípio da dignidade apoia-se em "três grandes pilares: o direito à vida e à existência digna, aqui incluído o direito à integridade física e psíquica, o direito à liberdade e o direito à igualdade ou à isonomia", os quais "além de conteúdo de dignidade, são também direitos da personalidade".

Nesse diapasão, Monteiro e Silva (2010, p.33) ressaltam que a dignidade da pessoa no seio familiar só será preservada se houver o respeito aos direitos da personalidade, uma vez que a família, antes mesmo de ser considerada célula básica da sociedade, "deve ser havida como centro de preservação da pessoa, da essência do ser humano".

\title{
2.3 Princípio da solidariedade
}

O princípio em tela encontra-se expresso no texto da Constituição Federal em seu artigo 3ํ, I, o qual reza que é objetivo fundamental da República Federativa do Brasil "construir uma sociedade livre, justa e solidária".

O princípio da solidariedade também é reconhecido nos artigos 226, 227 e 230 da Lei Maior, os quais impõem à sociedade, ao Estado e à família o dever de proteção ao grupo familiar, à criança e ao adolescente, bem como às pessoas idosas.

Tartuce (2011, p.988) entende que é solidário aquele que responde e se preocupa com o outro, de modo que "a solidariedade familiar deve ser tida em sentido amplo, tendo caráter afetivo, social, moral, patrimonial, espiritual e sexual".

Nesse raciocínio discorrem

\begin{abstract}
A solidariedade, portanto, culmina por determinar o amparo, a assistência material e moral recíproca, entre todos os familiares, em respeito ao princípio maior da dignidade da pessoa humana. É ela, por exemplo, que justifica a obrigação alimentar entre parentes, cônjuges ou companheiros, ou, na mesma linha, que serve de base ao poder familiar exercido em face dos filhos menores. (GAGLIANO E PAMPLONA FILHO, 2011, p.93).
\end{abstract}

Em relação aos filhos a solidariedade "responde a exigência da pessoa de ser cuidada até atingir a idade adulta, isto é, de ser mantida, instruída e educada para sua plena formação social” (MASSIMO 1989 apud LÔBO, 2011, p.64), em outras 
palavras o princípio da solidariedade respalda e fundamenta a imposição legal do efetivo exercício do poder familiar, o qual "é menos "poder" dos pais e mais múnus ou serviço que deve ser exercido no interesse dos filhos" (LÔBO, 2011, p.64).

\title{
2.4 Princípio da afetividade
}

Diniz (2010, p.24) entende o princípio da afetividade como sendo um "corolário do respeito da dignidade da pessoa humana, como norteador das relações familiares e da solidariedade familiar".

Para Lôbo (2011, p.70) o princípio da afetividade "fundamenta o direito de família na estabilidade das relações socioafetivas e na comunhão de vida, com primazia sobre as considerações de caráter patrimonial ou biológico".

O princípio em enfoque está implícito no texto da atual Constituição Federal, dentre os dispositivos nos quais incide, destaca-se aquele que: confere a igualdade entre os filhos havidos ou não do casamento, ou adotados (art. 227, § 6º); reconhece a comunidade formada por qualquer dos pais e seus descendentes, incluindo-se os adotivos, como entidade familiar (art. 226, $\S 4^{\circ}$ ); bem como o que assegura à Criança e ao Adolescente o convívio familiar como prioridade absoluta (art. 227) (LÔBO, 2011, p.71).

Nesse sentido aduz

\begin{abstract}
O afeto talvez seja apontado, atualmente, como o principal fundamento das relações familiares. Mesmo não constando a expressão afeto do Texto Maior como sendo um direito fundamental, pode-se afirmar que ele decorre da valorização constante da dignidade humana e da solidariedade. (TARTUCE, 2011, p.992).
\end{abstract}

A Constituição Federal de 1988 tutela o direito ao afeto, este consoante Barros (2006, p.884) constitui a liberdade que os indivíduos têm de afeiçoar-se uns aos outros, no entanto, adverte o doutrinador que "a afeição é um fato social jurígeno, que gera direitos e obrigações acerca de vários bens e valores, como alimentos, moradia, saúde, educação, etc."

Barros afirma que o afeto acarreta responsabilidade em virtude de sua função social, sendo que somente sob esta justificativa a Constituição admite o transtorno do exercício da afetividade, discorre o autor 
Entre certas categorias, a Constituição reconhece obrigação e direitos fundados originariamente no afeto, ao qual ela protege tão fortemente, que os vínculos persistem, mesmo se o afeto arrefecer. É o caso do art. 229 que determina que "os pais têm o dever de assistir, criar e educar os filhos menores, e os filhos maiores têm o dever de ajudar e amparar os pais na velhice, carência ou enfermidade". (BARROS, 2006, p.886-887).

Nesse prisma aduz Pereira (2006, p.850-851) "o princípio da afetividade nos faz entender e considerar que o afeto pressupõe também o seu avesso, já que o amor e o ódio são complementares ou são os dois lados de uma mesma moeda. Faltando o afeto, deve entrar a lei para colocar limites onde não foi possível pela via do afeto".

Todavia, segundo Lôbo afeto e afetividade são institutos distintos, data venia pode-se afirmar que enquanto aquele interliga os membros do grupo familiar por um vínculo emocional, esta os une através de um vínculo jurídico, consoante à lição abaixo transcrita

A afetividade, como princípio jurídico, não se confunde com o afeto, como fato psicológico ou anímico, porquanto pode ser presumida quando este faltar na realidade das relações; assim, a afetividade é dever imposto aos pais em relação aos filhos e destes em relação àqueles, ainda que haja desamor ou desafeição entre eles. O princípio jurídico da afetividade entre pais e filhos apenas deixa de incidir com o falecimento de um dos sujeitos ou se houver perda do poder familiar.[...] Na psicopatologia, por exemplo, a afetividade é o estado psíquico global com que a pessoa se apresenta e vive em relação às outras pessoas e aos objetos, compreendendo "o estado de ânimo ou humor, os sentimentos, as emoções e as paixões e reflete sempre a capacidade de experimentar sentimentos e emoções"71. Evidentemente essa compreensão abrangente do fenômeno é inapreensível pelo direito, que opera selecionando os fatos da vida que devem receber a incidência da norma jurídica. Por isso, sem qualquer contradição, podemos referir a dever jurídico de afetividade oponível a pais e filhos e aos parentes entre si, em caráter permanente, independentemente dos sentimentos que nutram entre si [...]. (LOBO, 2011, p.71)

Ante o exposto é possível afirmar que os pais não poderão invocar a falta de afeto ou amor para eximir-se dos deveres legais relativos a seus filhos, logo ainda que inexista afeição entre ambos, haverá o dever jurídico de afetividade, o qual somente deixará de existir em caso de morte ou perda do poder familiar.

\subsection{Princípio da convivência familiar}


A convivência familiar foi reconhecida como direito fundamental tanto por normas internacionais, quanto pelo ordenamento jurídico nacional, a Convenção das Nações Unidas sobre os Direitos da Criança, ratificada pelo Brasil em 21 de setembro de 1990, em seu artigo 9º, I, dispõe

Os Estados Partes garantem que a criança não é separada de seus pais
contra a vontade destes, salvo se as autoridades competentes decidirem,
sem prejuízo de revisão judicial e de harmonia com a legislação e o
processo aplicáveis, que essa separação é necessária no interesse superior
da criança. [...]. (BRASIL, 1990).

A atual Constituição Federal brasileira prevê que é dever da família, da sociedade e do Estado assegurar à criança e ao adolescente, com absoluta prioridade o direito à convivência familiar (CF\88, art.227), ao passo que reza o artigo 19 do Estatuto da Criança e do Adolescente que toda criança ou adolescente tem direito a ser criado e educado no seio da sua família.

Tamanha é a magnitude do direito em apreço que por decreto presidencial em 19 de outubro de 2004 foi criada uma Comissão Intersetorial para elaboração do Plano Nacional de Promoção, Proteção, e Defesa do Direito de Crianças e adolescentes à Convivência Familiar e Comunitária, "que pretende priorizar a recuperação do ambiente familiar, prevendo novas políticas públicas a fim de evitar o afastamento do convívio familiar" (MACIEL, 2010, p.76).

Ante o exposto resta apresentar o conceito de convivência familiar, que para Lôbo (2011, p.74) constitui "a relação afetiva diuturna e duradoura entretecida pelas pessoas que compõem o grupo familiar, em virtude de laços de parentesco ou não, no ambiente comum.

Por seu turno Maciel (2010, p.75) define a convivência familiar como sendo "o direito fundamental de toda pessoa humana de viver junto à família de origem, em ambiente de afeto e de cuidado mútuos, configurando-se um direito vital quando se tratar de pessoa em formação (criança e adolescente)."

O convívio familiar é imprescindível para um desenvolvimento psíquico saudável das crianças e adolescentes, a solidificar tal entendimento urge trazer à baila as palavras de Cabrera, Wagner Junior e Freitas Junior (2006, p.34) "A família é o ambiente natural para a concepção, formação e desenvolvimento do ser. É nesse ambiente que o indivíduo deverá proferir as primeiras palavras, ensaiar e desenvolver os primeiros passos, amar e ser amado". 
Dias assevera que a convivência dos filhos com seus pais constitui um direito daqueles e em contrapartida um dever destes, consoante o trecho abaixo transcrito

\begin{abstract}
O conceito atual de família, centrado no afeto como elemento agregador, exige dos pais o dever de criar e educar os filhos sem lhes omitir o carinho necessário para a formação plena de sua personalidade. A grande evolução das ciências que estudam o psiquismo humano veio a escancarar a decisiva influência do contexto familiar para o desenvolvimento sadio de pessoas em formação. Não se podendo mais ignorar essa realidade, passou-se a falar em paternidade responsável. Assim, a convivência dos filhos com os pais não é direito, é dever. Não há direito de visitá-lo, há obrigação de conviver com ele. (DIAS, 2010, p. 452)
\end{abstract}

Segundo Venosa "falta com o dever de pai ou mãe quem, podendo, descumpre o dever de convivência", sendo que o abalo psicológico provocado por tal negligência configurará um dano moral, ipsis litteris

\begin{abstract}
Assim, sustenta-se modernamente, com razão, que ofende a dignidade do filho não só a ausência do socorro material, como a omissão no apoio moral e psicológico. $\mathrm{O}$ abandono intelectual do progenitor com relação a filho menor gera, sem dúvida, traumas que deságuam no dano moral. Nesse diapasão, a afetividade liga-se inexoravelmente à dignidade do ser humano. (VENOSA, 2012, p.300-301).
\end{abstract}

Cumpre salientar, que conforme o Estatuto da Criança e do Adolescente (art. 23) e o vigente Código Civil (art. 1632) a falta de condições financeiras, a separação judicial, o divórcio e a dissolução da união estável não justificam a negligência dos pais em conviver, criar, educar e amparar moralmente seus filhos, estes somente em casos excepcionais poderão ser afastados definitivamente da família natural, a exemplo da adoção, do reconhecimento da paternidade socioafetiva ou da destituição do poder familiar (GAGLIANO; PAMPLONA FILHO, 2011, p.102).

\title{
2.6 Princípio do melhor interesse da criança e do adolescente
}

Após a Lei 8.069/1990 os menores de 18 anos deixaram de ser vistos como "peso social" ou até mesmo como "quase culpados pela própria condição de vítima", passando a serem considerados como verdadeiros sujeitos de direitos (HATEM, 2013, p.163).

O Estatuto da Criança e do Adolescente adotou a doutrina da proteção integral dos direitos das crianças e adolescentes, sendo que todos os seus direitos, sejam de cunho nacional ou internacional, são tutelados pelo Estado.

Explana 
A doutrina da proteção integral dos direitos supõe que o sistema legal garanta a satisfação de todas as necessidades de todas as crianças e adolescentes de 0 a 18 anos de idade (ECA, art.2o), privilegiando, sobretudo, seu direito à vida, à saúde, à convivência familiar e comunitária, ao lazer, ao esporte, à profissionalização, à liberdade, enfim, todos os direitos da pessoa humana (CF, art.227). (LIBERATI, 2010, p.15).

Oriunda da Convenção das Nações Unidas sobre os Direitos da Criança, a aludida doutrina garante a proteção aos direitos de todos os menores, não apenas daqueles em situação irregular, classificados como carentes, abandonados ou infratores, "mas deve dirigir-se a todas as crianças e a todos os adolescentes, sem distinção.

Foi também a partir da retro transcrita Convenção que o princípio do melhor interesse da criança e do adolescente ganhou maior destaque no Direito Pátrio, assim o descrito pelo seguinte autor

Trata-se de princípio orientador tanto para o legislador como para o aplicador, determinando a primazia das necessidades da criança e do adolescente como critério de interpretação da lei, deslinde de conflitos, ou mesmo para a elaboração de futuras regras. (AMIN, 2010, p.28)

Ainda segundo Amin os direitos infanto-juvenis devem prevalecer em detrimento dos direitos da própria família, constituindo um dever de todos garantir que os mesmos se materializem, in verbis

Indispensável que todos os atores da área infanto-juvenil tenham claro para si que o destinatário final de sua atuação é a criança e o adolescente. Para eles é que se tem que trabalhar. É o direito deles que goza de proteção constitucional em primazia, ainda que colidente com o direito da própria família.[...] Princípio do melhor interesse é, pois, o norte que orienta todos aqueles que se defrontam com as exigências naturais da infância e juventude. Materializá-lo é dever de todos. (AMIN, 2010, p.28)

Hatem aduz que crianças e adolescentes por serem pessoas em desenvolvimento configuram as partes hipossuficientes na relação familiar, daí o fato de merecerem que o Estado proteja e priorize seus direitos, assevera a autora

Contudo, a proteção ao melhor interesse do menor de 18 anos requer como argumentação máxima de sua justificativa o fato de que crianças e adolescentes são cidadãos, sujeitos de direitos e que, como seres em formação e desenvolvimento precisam de cuidados e atenção especiais, inclusive recebendo tratamento priorizado de ordem da própria legislação. (Hatem, 2013, p.170-171). 


\title{
Brilhantemente arremata
}

\begin{abstract}
A bem da verdade, o Princípio em tela é, portanto, um dos pilares do Direito de Família, devendo pautar todas as relações familiares bem como ações referentes à dissolução da sociedade conjugal, guarda, tutela, adoção, e as demandas relativas ao estado de filiação e aos alimentos, a título de exemplo, e, enfim, determinando que em todas essas situações será atendido, prioritariamente, 0 interesse de crianças $e$ adolescentes envolvidos, garantindo-se, portanto, em primeiro lugar, a satisfação daquilo que se demonstrar melhor a fim de suprir as necessidades e proteger esses cidadãos, que se encontram em desenvolvimento. (Hatem, 2013, p.173).
\end{abstract}

Por todo o exposto, conclui-se que tanto o Poder Executivo, Legislativo e Judiciário, bem como a família e toda a sociedade, devem primar pelo bem-estar, pelo saudável desenvolvimento físico e psíquico dos menores de 18 anos, enquanto pessoas em formação, para tanto se faz necessário que todos respeitem e efetivem os direitos que lhes são legalmente garantidos, sempre priorizando os interesses que melhor atendam as suas necessidades, ainda que colidentes com quaisquer outros.

\subsection{Princípio da prioridade absoluta}

O princípio da prioridade absoluta encontra fundamento no preceito do artigo $3^{\circ}$ da Convenção das Nações Unidas sobre os direitos da Criança, o qual reza "que todas as ações relativas às crianças, levadas a efeito por instituições públicas ou privadas de bem-estar social, tribunais, autoridades administrativas ou órgãos legislativos, devem considerar primordialmente, o interesse maior da criança".

A Constituição Federal recepcionou a proposta da primazia dos interesses infanto-juvenis conforme se infere do disposto no seu artigo 227, ipsis litteris

Art. 227. É dever da família, da sociedade e do Estado assegurar à criança, ao adolescente e ao jovem, com absoluta prioridade, o direito à vida, à saúde, à alimentação, à educação, ao lazer, à profissionalização, à cultura, à dignidade, ao respeito, à liberdade e à convivência familiar e comunitária, além de colocá-los a salvo de toda forma de negligência, discriminação, exploração, violência, crueldade e opressão. (BRASIL, 1988).

As crianças e adolescentes fazem jus a proteção especial de seus direitos, devendo ter atendimento prioritário de suas necessidades, em virtude de serem pessoas em condição "natural fragilidade ou por estarem numa fase em que se completa sua formação com riscos maiores" (LIBERATI, 2010, p.16). 
Amin obtempera que o princípio em tela

Estabelece primazia em favor das crianças e adolescentes em todas as esferas de interesses. Seja no campo judicial, extrajudicial, administrativo, social e familiar, o interesse infanto-juvenil deve preponderar. Não comporta indagações ou ponderações sobre o interesse a tutelar em primeiro lugar, já que a escolha foi realizada pela nação através do legislador constituinte. (AMIN, 2010, p.20).

Também o Estatuto da Criança e do Adolescente prevê em seu parágrafo único, artigo 4ํㅜ a absoluta prioridade dos menores de 18 anos em receber socorro, seja qual for a circunstância, no atendimento nos serviços públicos, na formulação e na execução das políticas sociais públicas, bem como na destinação de recursos públicos nas áreas relacionadas à proteção da infância e juventude.

Ressalta-se que o rol de prioridades elencado no dispositivo supra mencionado é meramente exemplificativo, uma vez que as necessidades e interesses infanto-juvenis devem ser primados em detrimento de quaisquer outros, em qualquer esfera da sociedade e em qualquer situação.

O tratamento diferenciado despendido pela Constituição e normas infraconstitucionais a crianças e adolescentes não fere o princípio da igualdade, "porque propõe uma nova condição especial (condição peculiar de desenvolvimento) daqueles sujeitos de direitos" (LIBERATI, 2010, p.18).

\section{DO DEVER DOS PAIS DE PRESTAR ASSISTÊNCIA IMATERIAL AOS FILHOS}

Consoante Tartuce (2011, p.1139-1140) poder familiar é "uma decorrência do vínculo jurídico de filiação, constituindo o poder exercido pelos pais em relação aos filhos, dentro da idéia de família democrática, do regime de colaboração familiar, e de relações baseadas, sobretudo, no afeto".

Segundo Venosa (2011, p.303-304) o pátrio poder, atualmente denominado poder familiar, é "o conjunto de direitos e deveres atribuídos aos pais com relação aos filhos menores e não emancipados, com relação à pessoa destes e a seus bens".

Gagliano e Pamplona Filho (2011, p.586) entendem o poder familiar "como o plexo de direitos e obrigações reconhecidos aos pais, em razão e nos limites da 
autoridade parental que exercem em face dos seus filhos, enquanto menores e incapazes".

Nesse mesmo diapasão Lôbo (2011, p.302) aduz que apesar de o aludido instituto constituir um conjunto de direitos e deveres, estes têm por finalidade o interesse da criança e do adolescente.

O poder familiar consiste num múnus público, vez que é o Estado quem estabelece as normas que regulam seu exercício e prima para que seja bem desempenhado, sendo assim, caracteriza-se por ser irrenunciável (insuscetível a qualquer tipo de transação), indelegável (não podendo ser transferido ou substabelecido a pessoa diversa dos pais) e imprescritível (não decaindo o direito dos pais de exercê-lo) (GONÇALVES, 2013, p.417).

Gonçalves (2013, p.417), em consonância com o artigo 1630 do vigente Código Civil, leciona que os filhos "menores não emancipados, havidos ou não no casamento ou resultantes de outra origem, desde que reconhecidos, bem como os adotivos" enquanto perdurar sua incapacidade estarão sujeitos ao poder familiar.

Por seu turno, com o advento da Constituição Federal de 1988 tanto o pai, quanto a mãe são titulares do poder familiar em igualdade de condições, conforme o disposto no artigo 226, $\S 5^{\circ}$ : "os direitos e deveres referentes à sociedade conjugal são exercidos igualmente pelo homem e pela mulher".

Sendo assim não há mais que se utilizar a expressão pátrio poder "totalmente superada pela despatriarcalização do Direito de Família, ou seja, pela perda do domínio exercido pela figura paterna no passado" (TARTUCE, 2011, p.1139).

Aderiram ao princípio constitucional da igualdade de gêneros o Estatuto da Criança e do Adolescente em seu artigo 21, assim como o Código Civil de 2002 em seu artigo 1631, este reza que "durante o casamento e a união estável, compete o poder familiar aos pais; na falta ou impedimento de um deles, o outro o exercerá com exclusividade", complementa o parágrafo único que em caso de divergência entre os pais quanto ao exercício do poder familiar, pode qualquer deles socorrer-se do Poder Judiciário para solucionar o desacordo.

A separação judicial, o divórcio e a dissolução da união estável não culminam na perda do poder familiar, não alterando a relação entre pais e filhos "senão quanto ao direito, que aos primeiros cabe, de terem em sua companhia os segundos" (CC, art. 1632).

A corroborar o acima expendido urge transcrever a sintética lição 
Nenhum dos pais perde o exercício do poder familiar com a separação judicial ou divórcio. O pátrio poder ou poder familiar decorre da paternidade e da filiação e não do casamento, tanto que o mais recente Código se reporta também à união estável. A guarda normalmente ficará com um deles, assegurado ao outro o direito de visitas. Atualmente, não é afastada a possibilidade de guarda compartilhada, como vimos, na qual, por períodos definidos ou concomitantemente, ambos os cônjuges a exercem.[...] É certo que 0 cônjuge que não detém a guarda tem, na prática, os poderes do pátrio familiar enfraquecidos. O cônjuge, no entanto, nessa situação, pode recorrer ao judiciário quando entender que o exercício direto do pátrio poder pelo guardião não está sendo conveniente. Aplica-se mesma conclusão à separação de fato e às uniões sem casamento. (VENOSA, 2011, p.305)

Logo, a ruptura da sociedade conjugal não é motivo hábil a justificar a ausência da mãe ou do pai não guardião, visto que seu direito de ter a companhia dos filhos está amparado pela legislação pátria, podendo ser reivindicado judicialmente quando obstaculizado.

Ademais, ter os filhos em sua companhia não constitui tão somente um direito, mas também um dever legalmente imposto aos pais, nesse sentido obtempera

O "direito à companhia" é relativo e não pode ser exercido contrariamente ao interesse do filho, que deve ter assegurado o direito à companhia do pai ou mãe que não seja o guardião. $O$ direito de um não exclui o direito do outro e o filho tem direito à companhia de ambos. (LÔBO, 2011, p.302).

De acordo com Tartuce o artigo 1632 supracitado ao dispor a inalterabilidade da relação entre pais e filhos ante a dissolução da sociedade conjugal

Acaba trazendo o direito à convivência familiar e, ao seu lado, um dever dos pais de terem os filhos sob sua companhia. Nessa norma reside fundamento jurídico substancial para a responsabilidade civil por abandono afetivo, eis que a companhia inclui o afeto, a interação entre pais e filhos. (TARTUCE, 2011, p.1139-1140)

A Constituição Federal em seu artigo 229 atribui aos pais o dever de "assistir, criar e educar os filhos menores", em consonância com a Lei Maior o Código Civil de 2002 elenca dentre as competências inerentes ao poder familiar, que é dever dos pais dirigir a criação e educação dos filhos menores, bem como tê-los em sua companhia e guarda.

Por sua vez, o Estatuto da Criança e do Adolescente em seu artigo 22 prevê que incumbe aos pais o dever de "sustento, guarda e educação dos filhos menores, 
cabendo-Ihes ainda, no interesse destes, a obrigação de cumprir e fazer cumprir as determinações judiciais".

Os aludidos deveres são de cunho imaterial, portanto o pai ou mãe não guardião além de cumprir com o dever de sustento dos filhos por meio da pensão alimentícia, tem o dever de prestar-Ihes a assistência imaterial.

Corrobora esse entendimento o renomado doutrinador Pereira advertindo para a insuficiência da mera prestação alimentícia no desenvolvimento dos filhos

$\mathrm{Na}$ assunção de seus papéis de pais, os genitores não devem limitar seus encargos ao aspecto material, ao sustento. Alimentar o corpo, sim, mas também cuidar da alma, da moral, da psique. Essas são prerrogativas do "poder familiar" e, principalmente, da delegação de amparo aos filhos. (PEREIRA, 2011, p. 668).

Hironaka (2013, on line) após conceituação e análise dos deveres legais paternos de sustento, educação e guarda, aduz que a negligência paterna quanto à educação da prole constitui o fator caracterizador do abandono afetivo, preleciona a aludida autora

\begin{abstract}
O abandono afetivo se configura, desta forma, pela omissão dos pais, ou de um deles, pelo menos relativamente ao dever de educação, entendido este na sua acepção mais ampla, permeada de afeto, carinho, atenção, desvelo. Esta a fundamentação jurídica para que os pedidos sejam levados ao Poder Judiciário, na medida em que a Constituição Federal exige um tratamento primordial à criança e ao adolescente e atribui o correlato dever aos pais, à família, à comunidade e à sociedade. (on line).
\end{abstract}

Nesse contexto, Lôbo aduz que o descumprimento da assistência imaterial aos filhos acarreta nestes um dano moral passível de indenização, in verbis

\footnotetext{
Entendemos que o princípio da paternidade responsável estabelecido no art. 226 da Constituição não se resume ao cumprimento do dever de assistência material. Abrange também a assistência moral, que é dever jurídico cujo descumprimento pode levar à pretensão indenizatória. $\mathrm{O}$ art. 227 da Constituição confere à criança e ao adolescente os direitos "com absoluta prioridade", oponíveis à família - inclusive ao pai separado -, à vida, à saúde, à educação, ao lazer, à dignidade, ao respeito e à convivência familiar, que são direitos de conteúdo moral, integrantes da personalidade, cuja rejeição provoca dano moral. O poder familiar do pai separado não se esgota com a separação, salvo no que concerne à guarda, permanecendo os deveres de criação, educação e companhia (art. 1.634 do Código Civil), que não se subsumem na pensão alimentícia. (LOBO, 2011, p.311-312).
} 
Ainda de acordo com o referido autor o abandono afetivo constitui justamente o inadimplemento dos deveres jurídicos de paternidade e não se restringe ao âmbito da moral, vez que o direito "o atraiu para si, conferindo-lhe conseqüências jurídicas que não podem ser desconsideradas", daí o fato de ser possível a responsabilização civil "para quem descumpre o múnus inerente ao poder familiar".

Assevera-se veementemente que os titulares do poder familiar

[...] não têm "opção" de exercê-lo, mas o dever de desempenhar a competência recebida. [...] Apesar de surgir como uma situação de proeminência ou vantagem sobre os filhos, seu exercício é obrigatório [...] $\mathrm{O}$ descumprimento destas competências que compõem o poder familiar, se causarem dano ao menor, tornar-se-á passível de reparação civil, entre outras sanções aplicáveis. (NAVES E SOUZA, 2013, p.139-140).

Portanto, além da possibilidade de o filho prejudicado pela desídia de um ou ambos os pais pleitear indenização por danos morais quando completados os 18 anos de idade, período que começa a contagem do prazo prescricional, os pais descumpridores dos deveres atinentes aos filhos, poderão ter o exercício do poder familiar suspenso (CC, art.1637) ou até mesmo vir a perdê-lo, conforme o disposto no artigo 1638, I, II, III e IV do Código Civil.

Tal solução segundo Pereira (2011, p. 674) é menos sanção e mais um prêmio ao pai negligente que com a "chancela judicial" estará desincumbido do dever legal de conviver com os filhos por ele desprezados.

O descumprimento das competências inerentes ao poder familiar também poderá ensejar sanções na esfera criminal, previstas nos artigos 244 e 246 do Código Penal - DECRETO-LEI N².848, de 7 de Dezembro de 1940, os quais tipificam respectivamente o abandono material e intelectual, in verbis

Art. 244. Deixar, sem justa causa, de prover a subsistência do cônjuge, ou de filho menor de 18 (dezoito) anos ou inapto para o trabalho, ou de ascendente inválido ou maior de 60 (sessenta) anos, não lhes proporcionando os recursos necessários ou faltando ao pagamento de pensão alimentícia judicialmente acordada, fixada ou majorada; deixar, sem justa causa, de socorrer descendente ou ascendente, gravemente enfermo:

Pena - detenção, de 1 (um) a 4 (quatro) anos e multa, de uma a dez vezes o maior salário mínimo vigente no País.

Art. 246. Deixar, sem justa causa, de prover à instrução primária de filho em idade escolar:

Pena - detenção, de 15 (quinze) dias a 1 (um) mês, ou multa.

(BRASIL, 1940). 
A Constituição Federal de 1988 (art. 227) e a Declaração Universal dos Direitos da Criança (princípio $10^{\circ}$ ) prevêem que é dever de todos colocar a criança e o adolescente a salvo de toda forma de negligência, sendo que esta em seu $6^{\circ}$ dispõe que as crianças serão criadas num ambiente afetuoso, que além de segurança material deve propiciá-las a segurança moral.

Por todo o exposto resta evidente que assim como a assistência material, os filhos fazem jus a assistência moral ou imaterial, a qual constitui um direito destes e um dever jurídico de seus pais.

Assistir moralmente significa cumprir com o dever de cuidar, acompanhar, criar, educar, conviver, amparar psicologicamente a criança e o adolescente, deveres os quais constituem ao mesmo tempo competências inerentes ao poder familiar e direitos garantidos aos menores tanto pelo Direito pátrio quanto por normas internacionais.

Violado o direito-dever de assistência imaterial está configurado o "abandono afetivo", fato que acarretará além das demais sanções legalmente previstas, a responsabilização civil do pai ou mãe negligente, ou seja, uma vez comprovado que a conduta omissiva dos pais originou um dano moral ao filho, este poderá acioná-los judicialmente requerendo indenização pelo prejuízo psíquico provocado.

\section{DO DEVER DE REPARAR O DANO MORAL ORIUNDO DO ABANDONO AFETIVO}

\subsection{Configuração da responsabilidade civil por abandono afetivo}

Como exaustivamente abordado no presente trabalho o abandono afetivo nada mais é do que o inadimplemento do dever jurídico dos pais de prestar a assistência imaterial aos seus filhos.

\footnotetext{
Dessa forma, os casos levados a julgamento sob o fundamento do "abandono afetivo" não devem ser considerados sob o enfoque do afeto, mas do descumprimento de uma norma jurídica, em especial aquela que determina os poderes-deveres constituintes do poder familiar e funcionalizados em prol do filho menor. (NAVES E SOUZA, 2013, p.141).
}

Infelizmente são inúmeros os casos em que o pai ou mãe não guardião afasta-se dos filhos, negligenciando-os o amor, carinho, afeto e atenção, bem como 
descumprindo com as competências inerentes ao poder familiar, como tê-los em sua companhia, dirigindo-Ihes a criação e educação, fato que culmina na violação da garantia constitucional de convivência familiar.

Numa pesquisa desenvolvida junto ao Instituto de Psicologia da UERJ em que foram entrevistados 30 jovens acerca do relacionamento com os pais não guardiões após o divórcio destes com os detentores da guarda, alega um rapaz de 25 anos que "o cotidiano não mudou. O que mudou foi a presença, falta do pai", outro da mesma idade revela que o "contato era ruim, não era suficiente, era péssimo" (BRITO, 2006, p.536).

Hironaka (2013, on line) aduz que há muitos casos em que apesar de os pais conviverem diuturnamente com os filhos não cumprem com as obrigações atinentes aos filhos, delegando o dever de educação a terceiros ou à escola, sendo que a esta compete tão somente o dever de instrução e formação intelectual.

Segundo a autora supracitada é possível que um pai ou mãe fisicamente presente seja acionado judicialmente em virtude do mau desempenho das funções parentais, entretanto nestas hipóteses deve-se "redobrar a atenção a fim de não se permitir a instalação de pedidos abusivos, calcados no rancor e na mágoa, como é até costumeiro acontecer".

Logo, não se há de olvidar que o abandono afetivo pode vir a se consubstanciar mesmo na constância do casamento ou união estável, no entanto é mais nítido e frequente após a ruptura dos aludidos institutos ou ainda quando os mesmos nem que sequer existiram. Alguns pais ao constituir nova família ferem o princípio da igualdade da filiação dispensando atenção exclusiva à nova prole, abandonando os filhos advindos da união anterior, outros se omitem por crer que o pagamento de pensão alimentícia os exime das demais obrigações oriundas do poder familiar.

Nesse diapasão, uma jovem de 23 anos, participante da retro transcrita pesquisa ao falar do vínculo que ainda resta com seu pai, desabafou: "O contato que eu tenho agora é dependência financeira, se não fosse isso eu acho que ainda teria menos contato com ele do que eu tenho agora" (BRITO, 2006, p.539).

Também poderá ocorrer o afastamento do não guardião em virtude de 0 mesmo submeter sua prole à situação de risco ou perigo, caso em que prefere se afastar "para não colocar a saúde ou a vida de seus filhos em risco (como é o caso, 
por exemplo, de o genitor ser portador de uma grave doença infecto-contagiosa, alcoolismo mórbido, drogadição, doença mental etc.)" (HIRONAKA, 2013, on line).

Segundo Hironaka (2013, on line) aquele que detêm a guarda pode contribuir para o distanciamento entre o filho e a mãe ou pai não guardião obstaculizando o relacionamento entre ambos, entretanto há casos em que a "culpa" por tal distanciamento poderá ser imputada ao pai e a mãe conjuntamente, quando, por exemplo, fixam residência em cidades distantes ou deixam de se encontrar para evitar uma provável discussão ou briga.

Por fim, convém ressaltar que o abandono afetivo poderá decorrer do desconhecimento da paternidade, trata-se da hipótese de o genitor não ter sido informado da superveniência de prole após o ato sexual.

Schreiber (2009, p.178-179) salienta que inadimplência dos deveres pertencentes ao poder familiar justificam a responsabilização dos pais, pois se o ordenamento jurídico não prevê o dever de amar ou ter afeto pelos filhos, prevê as competências de sustento, guarda, companhia, criação e educação, caso sejam violados poderá o filho lesado pleitear indenização pelo dano causado, desde que este e os demais elementos da responsabilidade civil sejam demonstrados.

Em consonância com o artigo 186 do Código Civil pode-se afirmar que o primeiro elemento da responsabilidade civil por abandono afetivo a ser preenchido é a omissão dos pais em cumprir o dever jurídico de assistir imaterialmente seus filhos.

[...] tem-se entendido que a omissão adquire relevância jurídica, e torna o omitente responsável, quando este tem dever jurídico de agir, de praticar um ato para impedir o resultado, dever, esse, que pode advir da lei, do negócio jurídico ou de uma conduta anterior do próprio omitente [...] Em suma, só pode ser responsabilizado por omissão quem tiver o dever jurídico de agir, vale dizer, estiver numa situação jurídica que o obrigue a impedir a ocorrência do resultado. Se assim não fosse, toda e qualquer omissão seria relevante e, consequentemente, todos teriam contas a prestar à Justiça. ( CAVALIERI FILHO, 2012, p.26)

O pai ou mãe negligente em suas obrigações parentais viola o dever jurídico de agir, daí decorre a relevância de tal conduta para o Direito, bem como a responsabilização civil pelos danos morais causados aos filhos, uma vez que se tivesse agido teria evitado o resultado lesivo, qual seja a ocorrência de danos psicológicos. 
Para que surja o dever de indenizar por abandono afetivo além da conduta omissiva é imprescindível que a mesma esteja revestida de culpa lato sensu, o que significa dizer que aos filhos vítimas do dano moral incumbe o ônus de provar o dolo ou culpa stricto sensu de seus pais.

Todavia o Código Civil de 2002 não distingue dolo e culpa, tenha o pai ou mãe omitente agido com dolo, culpa grave ou mesmo levíssima deverá ressarcir integralmente o filho lesado (GONÇALVES, 2013, p.325).

Por seu turno a indenização será medida pela extensão do dano moral sofrido, mas poderá ser reduzida caso haja desproporção entre seu valor e o grau da culpa do responsável (CC. art. 944, parágrafo único).

Cumpre destacar que poderá eximir-se de culpa o pai ou mãe não guardião que em decorrência de determinada circunstância ficou impossibilitado de conviver com os filhos, leciona

\begin{abstract}
Assim, não se há falar em culpa do não guardião, sempre que se apresentar, por exemplo, fatores que o impedem de conviver com o filho, como será o caso da fixação do domicílio em distância considerável, que encareça os deslocamentos a fim do cumprimento do dever de educar e conviver, mormente em hipóteses de famílias menos abastadas, assim como na hipótese de doença do genitor que, a bem dos filhos, prefere se afastar para não os colocar em situação de risco, além, ainda, da comum hipótese de não se saber se, realmente, "este suposto incumprimento é imputável à própria omissão do genitor não-guardião ou aos obstáculos e impedimentos por parte do genitor guardião." (HIRONAKA, on line)
\end{abstract}

Estará igualmente isento de culpa o genitor que desconhece a existência de seus descendentes, neste caso não poderá ser imputada a responsabilidade civil por abandono afetivo ante a falta de um de seus elementos: a culpa.

A corroborar o acima expendido imperioso se faz trazer à baila a ementa da 3ํㅗำ Turma Cível do Egrégio Tribunal de Justiça do Distrito Federal, in verbis

DIREITO CIVIL. AÇÃO DE INDENIZAÇÃO. ABANDONO AFETIVO PELO GENITOR. NEXO DE CAUSALIDADE. AUSÊNCIA. DANO MORAL. NÃO CONFIGURADO. 1. A responsabilidade civil extracontratual, decorrente da prática ato ilícito, depende da presença de três pressupostos elementares: conduta culposa ou dolosa, dano e nexo de causalidade. 2. Ausente o nexo de causalidade entre a conduta omissiva do genitor e o abalo psíquico causado ao filho, não há que se falar em indenização por danos morais, porque não restaram violados quaisquer direitos da personalidade. 3 . Ademais, não há falar em abandono afetivo, pois que impossível se exigir indenização de quem nem sequer sabia que era pai. 4. Recurso improvido. (DISTRITO FEDERAL, Tribunal de Justiça, Apc: 20090110466999, Relator: Getulio de Moraes Oliveira, 2013, grifo do autor). 
Assim, somente será responsabilizado o pai ou a mãe que com sua conduta omissiva tenha de fato dado causa ao dano psíquico sofrido pelo filho, de acordo com Hironaka (on line) a dificuldade maior na configuração da responsabilidade civil por abandono afetivo está justamente em estabelecer o nexo de causalidade, ou seja, o liame entre a conduta omissiva e o dano vivenciado.

Com efeito, a perícia será de suma importância, pois além de constatar a existência do dano poderá estabelecer a sua causa, bem como a época em que os sintomas do dano sofrido pela criança começaram a se manifestar, "pois não se poderá imputar ao pai um dano que tenha se manifestado em época anterior ao abandono" (HIRONAKA, 2013, on line).

Há controvérsias no que tange a imputação de dano psíquico ao pai ou mãe que tenha se omitido após a maioridade ou capacidade dos filhos. Costa (2005, p.31) defende que "em relação aos filhos maiores de idade e capazes, não tem cabimento indenização pela ausência de afeto por parte dos pais, porque não estão em fase de formação da personalidade".

Em contrapartida Hironaka (2013, on line) obtempera que os estudos psicológicos não garantem que o desenvolvimento da personalidade esteja completo ao se atingir a plena capacidade, para a autora este é "um assunto a ser pensado e cuidadosamente tratado, no caso concreto, quando este se apresentar à consideração judicial".

O posicionamento da autora Costa se mostra adequado, pois, ainda que a personalidade continue se desenvolvendo, os filhos maiores e capazes já não estão mais sob o poder familiar dos pais, nesse raciocínio se faz oportuno transcrever a ementa da $3^{\underline{a}}$ Turma Cível do Tribunal de Justiça do Distrito Federal, in verbis

APELAÇÃO CÍVEL. DANO MORAL. ABANDONO AFETIVO. PRESCRIÇÃO. MAIORIDADE. 1. O poder familiar, com seus consectários de dever de cuidado e vigilância, cessa quando da ocorrência da maioridade do filho, de modo que as indenizações de ordem moral devem circunscrever a este período, razão esta que a prescrição para pretender indenizações por abandono afetivo, começa a contar da maioridade, ainda que o reconhecimento da paternidade seja em data posterior. 2. Apelação improvida. (DISTRITO FEDERAL, Tribunal de Justiça, Apc: 20120510075984, Relator: Getulio de Moraes Oliveira, 2013, grifo do autor).

No que concerne ao início do prazo prescricional acima mencionado versa a ementa da $7^{\text {a }}$ Câmara Cível do Tribunal de Justiça do Rio Grande do Sul 
INDENIZAÇÃO. DANO MORAL. ABANDONO AFETIVO. MAIORIDADE. PRESCRIÇÃO. 1. Se a ação de indenização por dano moral decorrente de abandono afetivo foi proposta após o decurso do prazo de três anos de vigência do Código Civil de 2002, é imperioso reconhecer a prescrição da ação. Inteligência do art. 206, § 3으, inc. V, do CCB/2002. 2. O novo Código Civil estabeleceu a redução do prazo prescricional para as ações de reparação civil, tendo incidência a regra de transição posta no art. 2.028 do $\mathrm{CCB} / 2002$. 3. O pedido de reparação civil por dano moral, em razão do abandono afetivo, nada tem a ver com direito de personalidade, com direitos fundamentais ou com qualquer garantia constitucional, constituindo mera pretensão indenizatória, com caráter econômico, estando sujeita ao lapso prescricional. Recurso desprovido. (Apelação Cível № 70056484413, Sétima Câmara Cível, Tribunal de Justiça do RS, Relator: Sérgio Fernando de Vasconcellos Chaves, Julgado em 23/10/2013)

(RIO GRANDE DO SUL, Tribunal de Justiça, Ac: 70056484413, Relator: Sérgio Fernando de Vasconcellos Chaves, 2013).

Logo, conclui-se que o abandono afetivo paterno ou materno somente terá relevância jurídica quando praticado contra os filhos menores e incapazes, sendo que estes terão o prazo de três anos, contados a partir do momento em que completam a maioridade, para pleitear a indenização pelos danos morais ocasionados pela conduta omissiva dos seus pais.

\subsection{Posicionamento do Superior Tribunal de Justiça}

O primeiro caso acerca da responsabilidade civil dos pais por abandono afetivo a ser julgado pelo STJ foi o de Alexandre Batista Fortes por meio do Recurso Especial 757.411/MG.

Consoante o relatório do Acórdão, Alexandre alega que seu genitor Vicente de Paulo Ferro de Oliveira o abandonou psíquica e moralmente logo após ter se divorciado de sua mãe, época em que nasceu sua meia irmã advinda do novo relacionamento conjugal de seu pai.

Segundo Alexandre a conduta omissiva de seu genitor lhe causou extremo sofrimento e humilhação, fato que ensejou o ingresso com ação ordinária a fim de ver reparado os danos morais causados.

Em primeira instância o juiz de direito da 19a Vara Cível da Comarca de Belo Horizonte - MG julgou improcedente o pedido inicial, no entanto tal decisão foi reformada pelo Tribunal de Justiça de Minas Gerais que deu provimento ao recurso de apelação condenando o pai negligente ao pagamento de indenização por danos morais no valor de $R \$ 44.000,00$ (quarenta e quatro mil reais), a respectiva ementa reza "a dor sofrida pelo filho, em virtude do abandono paterno, que o privou do 
direito à convivência, ao amparo afetivo, moral e psíquico, deve ser indenizável, com fulcro no princípio da dignidade da pessoa humana",

A decisão foi submetida à apreciação do Superior Tribunal de Justiça, o qual em 29 de novembro de 2005 a reformou em sua integralidade, sendo que o relator ministro Fernando Gonçalves e os ministros Aldir Passarinho Junior, Jorge Scartezzini e Cesar Asfor Rocha votaram pelo provimento do recurso a fim de afastar a possibilidade de indenização nos casos de abandono afetivo.

Alegou o relator que em casos de abandono afetivo a perda do poder familiar é suficiente para cumprir a função punitiva e dissuasória; que a imposição aos pais de reparação pelos danos morais causados aos filhos culminaria no definitivo afastamento entre eles; e que a reparação financeira não faz sentido, uma vez que a pensão alimentícia por si só se encarrega de amparar o filho negligenciado afetivamente. Em suma concluiu que o Poder Judiciário não pode obrigar alguém a amar ou a ter um relacionamento afetivo, sendo assim a indenização pleiteada não cumpriria nenhuma função.

Barros Monteiro em seu voto vencido aduz que além do dever de assistência material o genitor possui o dever de "dar assistência moral ao filho, de conviver com ele, de acompanhá-lo e de dar-lhe o necessário afeto", ainda segundo o ministro o artigo 186 do Código Civil atual prevê a reparação por dano exclusivamente moral, estando presente no caso em tela a conduta ilícita, o dano e o nexo de causalidade e acrescentou que a destituição do poder familiar não impede a indenização por danos morais, sendo devidas as duas sanções.

Entretanto a resistência do Superior Tribunal de justiça perdurou somente até o dia 24 de abril de 2012, pois nesta data a Colenda Corte decidiu pelo cabimento de indenização por danos morais decorrentes do abandono afetivo, versa a ementa

CIVIL E PROCESSUAL CIVIL. FAMÍLIA. ABANDONO AFETIVO. COMPENSAÇÃO POR DANO MORAL. POSSIBILIDADE. 1. Inexistem restrições legais à aplicação das regras concernentes à responsabilidade civil e o consequente dever de indenizar/compensar no Direito de Família. 2. O cuidado como valor jurídico objetivo está incorporado no ordenamento jurídico brasileiro não com essa expressão, mas com locuções e termos que manifestam suas diversas desinências, como se observa do art. 227 da $\mathrm{CF} / 88$. 3. Comprovar que a imposição legal de cuidar da prole foi descumprida implica em se reconhecer a ocorrência de ilicitude civil, sob a forma de omissão. Isso porque 0 non facere, que atinge um bem juridicamente tutelado, leia-se, o necessário dever de criação, educação e companhia - de cuidado - importa em vulneração da imposição legal, exsurgindo, daí, a possibilidade de se pleitear compensação por danos morais por abandono psicológico. 4. Apesar das inúmeras hipóteses que 
minimizam a possibilidade de pleno cuidado de um dos genitores em relação à sua prole, existe um núcleo mínimo de cuidados parentais que, para além do mero cumprimento da lei, garantam aos filhos, ao menos quanto à afetividade, condições para uma adequada formação psicológica e inserção social. 5. A caracterização do abandono afetivo, a existência de excludentes ou, ainda, fatores atenuantes - por demandarem revolvimento de matéria fática - não podem ser objeto de reavaliação na estreita via do recurso especial. 6. A alteração do valor fixado a título de compensação por danos morais é possível, em recurso especial, nas hipóteses em que a quantia estipulada pelo Tribunal de origem revela-se irrisória ou exagerada. 7. Recurso especial parcialmente provido. (DISTRITO FEDERAL, Superior Tribunal de Justiça, Rel. Ministra Nancy Andrighi, 2012).

No Acórdão do julgado supra foi relatado que Luciane Nunes de Oliveira Souza impetrou ação de indenização por danos materiais e morais em face de seu pai Antônio Carlos Jamas, em virtude de este tê-la abandonado material e afetivamente durante sua infância e juventude.

O Juízo de primeiro grau julgou improcedente o pedido formulado pela filha negligenciada, aduzindo que o afastamento entre esta e seu genitor se deveu ao comportamento agressivo da mãe de Luciane após o término do relacionamento entre os genitores.

Interposto recurso de apelação perante o Tribunal de Justiça de São Paulo, o mesmo foi provido e o abandono afetivo reconhecido, sendo que pai omisso foi condenado ao pagamento, a título de compensação por danos morais, no importe de $R \$ 415.000,00$ (quatrocentos e quinze mil reais).

Por seu turno, Antônio Carlos recorreu da decisão e a matéria foi submetida à apreciação do Superior Tribunal de Justiça, a 3 ${ }^{\text {a }}$ Turma por maioria dos votos deu parcial provimento ao Recurso Especial n 1.159.242, condenando o pai negligente a reparação pecuniária do dano moral causado a filha, entretanto com redução do quantum para $\mathrm{R} \$ 200.000,00$ (duzentos mil reais).

Votou vencido o Sr. Ministro Massami Uyeda, ao passo que os Ministros Sidnei Beneti, Paulo de Tarso Sanseverino e Ricardo Villas Bôas Cueva votaram com a relatora a Sra. Ministra Nancy Andrighi.

A relatora em seu respeitável voto antes de adentrar no mérito, salientou que os dispositivos que regulam a responsabilidade civil "tratam do tema de maneira ampla e irrestrita, de onde é possível se inferir que regulam, inclusive, as relações nascidas dentro de um núcleo familiar, em suas diversas formas". 
No que tange a destituição do poder familiar como única sanção ao pai ou mãe negligente, aduz que esta medida repressiva não suprime, nem afasta a possibilidade de indenizações ou compensações.

Afirma a relatora que é crescente a percepção do cuidado como valor jurídico, que além de constituir um fator curial à formação da personalidade do infante, deve "ser alçado a um patamar de relevância que mostre o impacto que tem na higidez psicológica do futuro adulto".

Explana que o cuidado constitui uma obrigação legal, estando, portanto superado o argumento da "impossibilidade de se obrigar a amar" sempre utilizado nas discussões sobre o abandono afetivo, continua a relatora

\footnotetext{
Aqui não se fala ou se discute o amar e, sim, a imposição biológica e legal de cuidar, que é dever jurídico, corolário da liberdade das pessoas de gerarem ou adotarem filhos.

O amor diz respeito à motivação, questão que refoge os lindes legais, situando-se, pela sua subjetividade e impossibilidade de precisa materialização, no universo meta-jurídico da filosofia, da psicologia ou da religião.

O cuidado, distintamente, é tisnado por elementos objetivos, distinguindo-se do amar pela possibilidade de verificação e comprovação de seu cumprimento, que exsurge da avaliação de ações concretas: presença; contatos, mesmo que não presenciais; ações voluntárias em favor da prole; comparações entre o tratamento dado aos demais filhos - quando existirem -, entre outras fórmulas possíveis que serão trazidas à apreciação do julgador, pelas partes.

Em suma, amar é faculdade, cuidar é dever.

(DISTRITO FEDERAL, Superior Tribunal de Justiça, Rel. Ministra Nancy Andrighi, 2012, grifo do autor).
}

Por fim, Adrighi conclui que o descumprimento do dever de cuidado, neste compreendidos os deveres de criação, educação e companhia, configura um ilícito civil, sob a forma de omissão.

Entretanto, adverte que para a caracterização do dever de indenizar será preciso ainda comprovar a existência do dano e nexo causal, cuja constatação deve ser feita através de laudo elaborado por especialistas "que aponte a existência de uma determinada patologia e a vincule, no todo ou em parte, ao descuidado por parte de um dos pais".

Após minuciosa análise dos elementos da responsabilidade civil, a relatora considerou existente o dano moral causado pelo pai descumpridor do dever de cuidar de sua filha, estando presente no caso em tela a tríade: negligência, dano e nexo causal. 
A complementar o entendimento da relatora, importa salientar as ponderações feitas pelo ministro Paulo de Tarso Sanseverino, segundo ele a responsabilidade civil no direito de família apesar de cabível deve ser analisada com cautela e aplicada somente em casos excepcionalíssimos de nítido excesso na relação familiar.

Entende o ministro que o "abandono afetivo apenas ocorre quando o progenitor descumpre totalmente seu dever de cuidado, infringindo flagrantemente as mais comezinhas obrigações para com seu filho".

Ao final reconheceu que no caso em tela devido ao fato de o pai de Luciane ter resistido em reconhecê-la espontaneamente como filha, se negado a ampará-la materialmente, deixado de prestar-lhe o amparo moral, afetivo e psicológico, bem como buscado fraudulentamente alienar seus bens aos demais filhos, se furtou total e flagrantemente ao seu dever de cuidado, configurando-se assim o abandono afetivo e a consequente obrigação de reparar os danos provenientes do mesmo.

\section{CONCLUSÃO}

Prevê a Lei Maior que é dever de todos, ou seja, do Estado, da sociedade e da família proteger os direitos das crianças e adolescentes, sendo assim é inadmissível tolerar ou aceitar como normal que filhos sejam abandonados por aqueles de quem mais precisam: seus pais.

A expressão "abandono afetivo" foi adotada para o presente trabalho em virtude de ser a utilizada tanto pela doutrina, quanto pela jurisprudência pátria, todavia não está vinculada ao afeto ou ao amor, pois sentimentos além de subjetivos não são abarcados pelo Direito, logo o abandono afetivo deve ser compreendido como o descumprimento dos deveres legalmente impostos aos pais e inerentes ao poder familiar.

Aos pais não há a faculdade, mas o dever jurídico de cuidar de seus filhos, sendo que a inadimplência dos deveres parentais acarreta, principalmente nas crianças e adolescentes, sérios danos psíquicos que os acompanharam ad perpetuam, portanto em consonância com os artigos 186 e 927 do vigente Código Civil, uma vez comprovado que a omissão culposa dos pais deu causa ao dano moral sofrido pelos filhos, aqueles ficam obrigados a repará-lo. 
Não há que se falar em monetarização do afeto, pois negar o dano moral oriundo do abandono afetivo paterno ou materno como sendo passível de indenização seria um lastimável retrocesso jurídico, uma vez que antes do advento da Constituição Federal de 1988 considerava-se até imoral exigir reparação por danos exclusivamente extrapatrimoniais, sob o argumento de que não se pode precificar a dor, e atualmente em evidente retrocesso alega a doutrina minoritária que não se pode dar preço ao afeto ou ao amor.

Com a devida vênia, o argumento antagônico de que não se pode obrigar alguém a amar ou ter relação afetiva com outra pessoa é frágil e não tem o condão de afastar a responsabilidade civil em caso de abandono afetivo dos pais, pois evidentemente nem o Judiciário, nem ninguém possui esse poder de interferir nos sentimentos humanos, no entanto o enfoque da matéria não está no inexistente dever de amar, mas sim no positivado dever de cuidar, constante em princípios e em dispositivos constitucionais, infraconstitucionais, bem como em normas internacionais.

Se não há o dever de amar um filho, a partir do momento em que este é concebido ou adotado, nasce concomitantemente o dever moral e jurídico de cuidálo, educando-o, acompanhando-o, tendo-o em sua guarda e companhia, enfim propiciando a esse ser, cuja psique se mostra tão frágil na infância e adolescência, um saudável desenvolvimento de sua personalidade, de maneira que se torne um adulto equilibrado, seguro, apto a enfrentar os desafios da vida sem medos ou traumas, contribuindo de maneira positiva para o progresso da sociedade aonde vive.

Por outro lado, é no mínimo incoerente a alegação de que a destituição do poder familiar é suficiente a punir os pais que abandonam afetivamente sua prole, tal medida serviria de sanção ou de verdadeiro prêmio a pais negligentes? Se um pai ou uma mãe deliberadamente se afasta dos filhos, descumprindo com seus deveres parentais, negando-lhes a companhia, a atenção, o cuidado em sua acepção mais ampla, é óbvio que a decisão que decretar a perda do poder familiar soará como uma verdadeira "carta de alforria", um verdadeiro alívio àquele que a partir de agora poderá omitir-se em cuidar dos filhos sem infringir preceitos legais.

Outro argumento utilizado por juristas e doutrinadores considera que condenar o pai ou a mãe ao pagamento de indenização pelos danos morais sofridos pelo filho culminaria no afastamento definitivo entre estes, no entanto não cabe ao 
magistrado embasar suas decisões nos efeitos negativos, presumíveis ou até mesmo imprevisíveis que as mesmas poderão surtir, pois se assim fosse analogicamente poderia um devedor deixar de ser judicialmente cobrado e condenado ao pagamento da dívida, pelo fato de talvez alimentar sentimentos como ódio, rancor ou vingança contra o autor da ação.

Contudo, é unânime o entendimento dentre os adeptos da admissibilidade de reparação do dano moral fruto do abandono afetivo de que realmente não são todos os casos em que se verificará a presença dos pressupostos da responsabilidade civil, daí a importância crucial da análise de profissionais especializados na formulação de um laudo que demonstre se efetivamente houve a conduta omissiva do pai ou da mãe, se presente a culpa, se desta conduta omissiva culposa adveio um dano psíquico ao filho, bem como se existe o liame entre este e a omissão de cuidado de um dos pais.

Ademais, é imprescindível que o magistrado pondere, sopese e analise minuciosamente as peculiaridades de cada caso concreto, de modo a verificar se de fato os pais acionados judicialmente se omitiram flagrantemente em seu dever de cuidado ou se a demanda judicial foi intentada por outros motivos, que não o abandono afetivo, como vingança do próprio filho autor da ação ou do genitor que tem ou teve a sua guarda, bem como se existe algum fator que exima de culpa o réu ou exclua o nexo causalidade.

Apesar de alguns Tribunais já terem proferido decisões favoráveis a responsabilização civil dos pais em virtude do abandono afetivo, ainda é grande resistência na jurisprudência pátria acerca do tema, sendo que a grande maioria das demandas são julgadas improcedentes.

A pioneira decisão do Superior Tribunal de Justiça em que esta Corte admite a reparação pecuniária do dano moral ocasionado pelo abandono afetivo paterno caracteriza um incomensurável progresso no mundo jurídico e um ganho para a sociedade, pois fortalece a jurisprudência e serve de parâmetro para as novas ações a serem impetradas.

Anseia o presente trabalho que a partir de então os demais Tribunais brasileiros reconheçam o abandono afetivo dos pais como uma grave e intolerável afronta aos direitos das crianças e adolescentes e que brevemente a jurisprudência pátria majoritária se posicione a favor da responsabilização civil dos pais que se omitem em cumprir com o dever de cuidar de seus filhos, de modo que tal medida 
além de compensar os danos psíquicos causados, cumpra com sua função punitiva e pedagógica e sirva de exemplo, de desestímulo para que outros pais não incorram nesta prática que é tão nefasta, não só àqueles que são suas vítimas, mas também à própria nação que futuramente por elas será dirigida.

\section{REFERÊNCIAS}

AMIN, Andréa Rodrigues. Princípios orientadores do direito da criança e do adolescente. In: MACIEL, Kátia (coord.). Curso de Direito da Criança e do Adolescente: Aspectos Teóricos e Práticos. 4. ed. Rio de Janeiro: Lumen Juris, 2010.

BARROS, Sérgio Rezende de. A tutela constitucional do afeto. In: PEREIRA, Rodrigo da Cunha (coord.). Família e dignidade humana: $V$ congresso brasileiro de direito de família. São Paulo: IOB Thomson, 2006.

BRASIL. Constituição (1988). Constituição da República Federativa do Brasil: promulgada em 05 de Outubro de 1988. Disponível em:

<http://www.planalto.gov.br/ccivil_03/constituicao/constituicaocompilado.htm>. Acesso em: 15 set. 2013.

. Lei n. 10.406, de 10 de janeiro de 2002. Institui o Código Civil Brasileiro. Diário Oficial [da] República Federativa do Brasil. Poder Executivo. Brasília, DF 11 de Janeiro de 2002. Disponível em:

$<$ http://www.planalto.gov.br/ccivil 03/leis/2002/l10406.htm> Acesso em: 15 set. 2013.

. Lei Federal 8.069, de 13 de julho de 1990. Dispõe sobre o estatuto da criança e do adolescente, e dá outras providências. Diário Oficial [da] República Federativa do Brasil. Poder Executivo. Brasília, DF 16 de Julho de 1990. Disponível em: <http://www.planalto.gov.br/ccivil 03/Leis/L8069.htm>. Acesso em: 15 set. 2013.

. Senado Federal. Projeto de Lei do Senado PLS no 700/2007. Modifica a Lei no 8.069, de 13 de julho de 1990 (Estatuto da Criança e do Adolescente) para caracterizar o abandono moral como ilícito civil e penal, e dá outras providências. Disponível em:

<http://www.senado.gov.br/atividade/materia/detalhes.asp?p_cod_mate=83516>. Acesso em: 15 set. 2013.

. Câmara dos Deputados. Projeto de lei 4294/2008. Acrescenta parágrafo ao art. 1.632 da Lei no 10.406, de 10 de janeiro de 2002 - Código Civil e ao art. $3^{\circ}$ da Lei no 10.741, de $1^{\circ}$ de outubro de 2003 - Estatuto do Idoso, de modo a estabelecer a indenização por dano moral em razão do abandono afetivo. Disponível em: <http://www.camara.gov.br/proposicoesWeb/fichadetramitacao?idProposicao=41568 4.>. Acesso em: 17 mar. 2014.

. Superior Tribunal de Justiça. Recurso Especial Cível no 1159242 - SP (2009/0193701 - 9). Recorrente: Antônio Carlos Jamas Dos Santos. Recorrido: 
Luciane Nunes de Oliveira. Relator: Nancy Andrighi. São Paulo, 24 de abril de 2012.

LexML: Rede de informação Legislativa e Jurídica. Disponível em:

<http://www.lexml.gov.br/urn/urn:lex:br:superior.tribunal.justica;turma.3:acordao;

resp:2012-04-24;1159242-1185550>. Acesso em: 16 set. 2013.

. Superior Tribunal de Justiça. Recurso Especial no 757.411 - MG

(2005/0085464-3). Recorrente: Vicente de Paulo Ferro de Oliveira. Recorrido:

Alexandre Batista Fortes. Relator: Fernando Gonçalves. Belo Horizonte, 29 de novembro de 2005. JusBrasil. Disponível em:

$<$ http://stj.jusbrasil.com.br/jurisprudencia/7169991/recurso-especial-resp-757411-mg2005-0085464-3/inteiro-teor-12899597>. Acesso em: 04 set. 2013.

. Tribunal de Justiça do Distrito Federal. Apelação Cível 20090110466999.

Relator: Getúlio de Moraes Oliveira. Distrito Federal, 03 de julho de 2013. JusBrasil. Disponível em: http://tj-df.jusbrasil.com.br/jurisprudencia/23663893/apelacao-civelapc-20090110466999-df-0089809-1720098070001-tjdf. Acesso em: 02 abr. 2014.

. Tribunal de Justiça do Distrito Federal. Apelação Cível 20120510075984.

Relator: Getúlio de Moraes Oliveira. Distrito Federal, 12 de junho de 2013.

JusBrasil. Disponível em: http://tj-

df.jusbrasil.com.br/jurisprudencia/23597141/apelacao-civel-apc-20120510075984-df0007395-4220128070005-tjdf. Acesso em: 02 abr. 2014.

. Tribunal de Justiça do Rio Grande do Sul. Apelação Cível 70056484413.

Relator: Sérgio Fernando de Vasconcellos Chaves. Rio Grande do Sul, 23 de outubro de 2013. JusBrasil. Disponível em: http://tj-

rs.jusbrasil.com.br/jurisprudencia/113328649/apelacao-civel-ac-70056484413-rs.

Acesso em: 02 abr. 2014.

. Tribunal de Justiça de São Paulo. Processo nº 000.01.036747-0. Juiz Luís Fernando Cirillo. São Paulo, 07 de julho de 2004. Disponível em:

http://www.flaviotartuce.adv.br/index2.php?sec=jurisprudencia\&id=174. Acesso em: 15 abr. 2014.

BRITO, Leila Maria Torraca de. Desdobramento da família pós-divórcio: o relato dos filhos. In: PEREIRA, Rodrigo da Cunha (coord.). Família e dignidade humana: V congresso brasileiro de direito de família. São Paulo: IOB Thompson, 2006.

CABRERA, Carlos Cabral; WAGNER JUNIOR, Luiz Guilherme da Costa; FREITAS JUNIOR, Roberto Mendes de Freitas. Direitos da Criança do Adolescente e do Idoso. Belo Horizonte: Del Rey, 2006.

CAVALIERI FILHO, Sérgio. Programa de responsabilidade civil. 10. ed. São Paulo: Atlas, 2012.

CONVENÇÃO das Nações Unidas sobre Direitos da Criança. Aprovada pelo Decreto Legislativo $\mathrm{n}^{\circ}$ 28, de 14 de setembro de 1990 e Promulgada pelo Decreto 99.710 de 21 de novembro de 1990. Disponível em:

<https://www.google.com.br/gfe rd=cr\&ei=2G5qU7PuHMOU8Qfz4oG4AQ\#q=Conve 
n\%C3\%A7\%C3\%A3o+das+nac\%C3\%B5es+unidas+direito+da+crian\%C3\%A7a>. Acesso em: 23 abril 2014.

COSTA, Maria Isabel Pereira da. Família. Do autoritarismo ao afeto. Como e a Quem Indenizar a Omissão do Afeto? Revista Brasileira de Direito de Família. Porto Alegre, v.7, n.32, p.20-39, out./nov. 2005.

DELGADO, Mário Luiz. Direitos da personalidade nas relações de família. In: PEREIRA, Rodrigo da Cunha (coord.). Família e dignidade humana: V congresso brasileiro de direito de família. São Paulo: IOB Thomson, 2006.

DIAS, Maria Berenice. Manual de direito das famílias. 5. ed. São Paulo: Revista dos Tribunais, 2009.

. Manual de direito das famílias. 6. ed. São Paulo: Revista dos

Tribunais, 2010.

DINIZ, Helena Maria. Curso de direito civil brasileiro: direito de família. 25. ed. São Paulo: Saraiva, 2010.

GAGLIANO, Pablo Stolze; PAMPLONA FILHO, Rodolfo. Novo curso de direito civil: direito de família. São Paulo: Saraiva, 2011.

GONÇALVES, Carlos Roberto. Direito civil brasileiro: direito de família. 10. ed. São Paulo: Saraiva, 2013. v. 6.

HATEM, Daniela Soares. O princípio do melhor interesse da criança e a doutrina da proteção integral: diretrizes do direito de família visando à efetivação dos direitos preconizados no estatuto da criança e do adolescente. In: MARÇAL, Antônio Cota; PIMENTA, Eduardo Goulart; NUNES, Maria Emília Naves; MAGALHÃES, Rodrigo Almeida. (coord.). Os princípios na construção do direito. Rio de Janeiro: Lumen Juris, 2013.

HIRONAKA, Giselda Maria Fernandes Novaes. Pressupostos, elementos e limites do dever de indenizar por abandono afetivo. Disponível em:

$<$ thtp://www.google.com.br/urlsa=t\&rct=j\&q=\&esrc=s\&source=web\&cd=1\&ved=0CCo QFjAA\&url=http\%3A\%2F\%2Fwww.jusnews.com.br\%2Fportal\%2Findex2.php3Foptio n\%3Dcom_content\%26do_pdf\%3D1\%26id\%3D40\&ei=|4pqU-

KzltDQsQSxyoGAAw\&usg=AFQjCNEcarPjTBQ-4DFcT0GwtugicyaD1Q>. Acesso em: 11 set. 2013.

LIBERATI, Wilson Donizeti. Direito da criança e do adolescente. 4ed. São Paulo: Rideel, 2010.

LÔBO, Paulo. Direito civil: famílias. 4. ed. São Paulo: Saraiva, 2011.

MACIEL, Kátia Regina Ferreira Lobo Andrade. Direito fundamental à convivência familiar. In: MACIEL, Kátia (coord.). Curso de direito da criança e do adolescente: aspectos teóricos e práticos. 4. ed. Rio de Janeiro: Lumen Juris, 2010. 
MARÇAL, Antônio Cota. Metaprincípios do estado democrático de direito: um ponto de vista pragmatista. In: MARÇAL, Antônio Cota; PIMENTA, Eduardo Goulart; NUNES, Maria Emília Naves; MAGALHÃES, Rodrigo Almeida. (coord.). Os princípios na construção do direito. Rio de Janeiro: Lumen Juris, 2013.

MONTEIRO, Washington de Barros; SILVA, Regina Beatriz Tavares da. Curso de Direito Civil: direito de família. 40. ed. São Paulo: Saraiva, 2010.

NAVES, Bruno Torquato de Oliveira; SOUZA, lara Antunes. Da afetividade à responsabilidade: o pretenso "princípio jurídico da afetividade" no direito de família frente ao princípio da reparação integral na responsabilidade civil. In: MARÇAL, Antônio Cota; PIMENTA, Eduardo Goulart; NUNES, Maria Emília Naves; MAGALHÃES, Rodrigo Almeida. (coord.). Os princípios na construção do direito. Rio de Janeiro: Lumen Juris, 2013.

PAZZAGLINI FILHO, Marino. Princípios Constitucionais Reguladores da Administração Pública. 2. ed. São Paulo: Atlas, 2003.

PEREIRA, Rodrigo da Cunha. Uma principiologia para o direito de família. In: PEREIRA, Rodrigo da Cunha (coord.). Família e dignidade humana: $V$ congresso brasileiro de direito de família. São Paulo: IOB Thomson, 2006.

. Nem só de pão vive o homem. Disponível em:

<http://www.scielo.br/pdf/se/v21n3/a06v21n3.pdf>. Acesso em: 04 set. 2013.

SCHREIBER, Anderson. Novos paradigmas da responsabilidade civil: da erosão dos filtros da reparação à diluição dos danos. 2. ed. São Paulo: Atlas, 2009.

TARTUCE, Flávio. Manual de direito civil. São Paulo: Método, 2011.

VENOSA, Silvio de Salvo. Direito Civil: direito de família. 11. ed. São Paulo: Atlas, 2011.

Direito Civil: Responsabilidade Civil. 12. ed. São Paulo: Atlas, 2012. 